\title{
A SAÚDE BUCAL E A FITOTECNIA: AÇÕES INTERDISCIPLINARES DO ODONTÓLOGO E ENGENHEIRO AGRÔNOMO
}

\author{
Marilene da Cruz Magalhães Buffon \\ Orientador. Prof. Dr. Valdo José Cavallet
}

\begin{abstract}
RESUMO
O presente trabalho tem por objetivo discutir e apresentar uma possível relação interdisciplinar entre o cirurgião-dentista e o engenheiro-agrônomo, ambos visando a melhoria na qualidade de vida da população rural, através de medidas educativas e preventivas e com ações que contribuam para a construção da cidadania, com vistas ao paradigma social e ambiental. Visa também, apresentar a fitoterapia enquanto perspectiva de terapêutica adequada. As análises e sínteses foram baseadas em pesquisas descritivas bibliográficas. A população da zona rural, além de ser excluída dos levantamento epidemiológicos, não encontra os serviços de atenção básica a saúde, voltado as suas necessidades. Porém, esta população tem, na maioria das vezes, o engenheiro agrônomo como orientador e consultor dos seus problemas. Estudos epidemiológicos demonstram que a cárie dentária e a doença periodontal atingem uma grande parcela da população brasileira. Essas doenças são provocadas pela placa dentária, e a constante necessidade de se avaliar meios alternativos viáveis, baratos e seguros, para o controle da placa bacteriana, tem estimulado o estudo de plantas medicinais para este fim. Na área rural a fitoterapia pode ser indicada como um meio alternativo em programas preventivos, por um cirurgião dentista e um agrônomo-educador, na tentativa de mudança nas atitudes dos agricultores, promovendo e mantendo a saúde, buscando assim a melhoria na qualidade de vida.
\end{abstract}

\begin{abstract}
This work aims to discuss and present a possible interdisciplinary relation between the dentist and the agronomy engineer, both focusing on the improvement of the rural population's quality of life, through preventive and educational measures that contributes to the citizenship construction, having in view the social and the environmental paradigm. It also aims to present the phytotherapy as an adequate therapeutics perspective. The analysis and synthesis new based on descriptive bibliographic research. The rural population, besides being excluded from epidemiological statistics, do not have access to basic health care. However this population do have, in most of the times, the agronomy engineer as an adviser and guide to their problems. Epidemiological studies show that caries and periodontal disease affect a large proportion of Brazilian inhabitants. These diseases are caused by plaque. The constant necessity to evaluate viable alternatives, which are cheap and safe, to the plaque control, has stimulated studies of medicinal plants to this issue. In rural areas, phytotherapy may be indicated as an alternative in preventive programs, through an dentist and an agronomist-educator,
\end{abstract}

trying to change the agriculturist's attitudes, promoting health improvement, and a better quality of life. 